\title{
Engaging and Empowering Community Resource Organizations (CROs) Before, During, and After Disasters ${ }^{1}$
}

\author{
Angela B. Lindsey and Samantha Goldenberg ${ }^{2}$
}

\section{Healthy Gulf, Healthy Communities Project}

The Healthy Gulf, Healthy Communities (HGHC) project, funded by the National Institute of Environmental Health Sciences (NIEHS), works with communities impacted by the 2010 Deepwater Horizon oil spill to conduct research on resiliency and seafood safety. The aftermath of the DWH oil spill prompted a University of Florida (UF)-led team of researchers to study the physiological, psychological, and sociological effects in order to help communities recover and prepare for future potential disasters.

\section{HGHC Series Overview}

The HGHC EDIS Series includes thirteen publications that focus on the work of the community outreach and dissemination team, including community engagement, outreach, and research result dissemination. Community engagement, outreach, and dissemination will serve as the basis for this series of EDIS publications entitled "Healthy Gulf, Healthy Communities Series". Thirteen publications constitute this series, with topics focusing on the work of the community outreach and dissemination team. This is the second publication in the series and focuses on engaging community organizations before and after a disaster.

\section{Introduction}

Each community has organizations that contribute to the social capital of a community and improve the quality of community life. These organizations can often fill a gap or need within a community and/or provide support and serve as a resource for community members. During and after a crisis, the value of these organizations is increased, as they offer much-needed social and economic services. These organizations are often instrumental in helping communities prepare and recover from disasters. Collaboration among these groups following disasters is often very organic as they come together reactively to meet immediate needs and services. However, developing these collaborative groups prior to a disaster can be beneficial for disaster preparedness and disaster recovery.

\section{Community Resource Organizations (CROs)}

The term CRO is very common in medical literature when referring to organizations that provide services for patients outside of medical needs. They are often called upon to address the social needs of patients. The term has since been adapted to social science research and defined more broadly to include a person, physical structure, community

1. This document is AEC656, one of a series of the Department of Agricultural Education and Communication, UF/IFAS Extension. Original publication date December 2018. Visit the EDIS website at https://edis.ifas.ufl.edu for the currently supported version of this publication.

2. Angela B. Lindsey, assistant professor, Department of Family, Youth and Community Sciences, UF/IFAS Center for Public Issues Education in Agriculture and Natural Resources; and Samantha Goldenberg, graduate student, Department of Family, Youth and Community Sciences; UF/IFAS Extension, Gainesville, FL 32611.

The Institute of Food and Agricultural Sciences (IFAS) is an Equal Opportunity Institution authorized to provide research, educational information and other services only to individuals and institutions that function with non-discrimination with respect to race, creed, color, religion, age, disability, sex, sexual orientation, marital status, national origin, political opinions or affiliations. For more information on obtaining other UF/IFAS Extension publications, contact your county's UF/IFAS Extension office. 
service, nonprofit, or business that provides a much-needed service or resource to a community. Given their value during a personal difficult time and/or crisis, their significance before and after a disaster is crucial. Miller (2009) references CROS as "pillars of strength" that people expect to stay strong and be there for them in times of turmoil.

\section{Why have CROS involved? How can CROS work collaboratively to help?}

During times of disaster, cross-sector collaboration should be used. This involves joining governments, businesses, CROs, communities, and the public in developing shared goals and outcomes (Simo \& Bies, 2007). These multiorganizational collaborations are often referred to as workgroups and are helpful if one sector is especially weak or lacking. Workgroups can often bring a more organized and structured assistance during a chaotic time. They are available to help solve problems and respond to the immediate needs of the community by creating more effective response and recovery operations that may not have been accessible without their involvement.

There are three main ways that these collaborative workgroups can assist during disasters. These include better implementation strategies and decision making, improved community involvement and commitment, and more collective action and capacity building (Kapucu, Yuldhasev, \& Feldheim, 2011). When CROs are implemented in disaster relief, it automatically creates collaborations due to these organizations working together to quickly address gaps and needs. These collaborations then strengthen the community by allowing community members to participate in developing disaster programs.

Volunteers from CROs are another major advantage to collaborations because they are able to provide extra help that may not have otherwise been offered without the CROs involvement. These volunteers have a desire to be included and are usually already trained or can be trained to help in future disasters (Word \& Brower, 2012). The organizations and community members are able to build a trusting relationship based on communication that can then be used in similar disaster situations (Kapucu, 2006).

\section{Disaster Preparedness and Recovery Organizations}

Disaster preparedness and recovery is at the core of the mission of many local, state, and national collaborations. For example, the National Voluntary Organizations Active in Disaster (NVOAD) is an organization made up of other nonprofit organizations that come together by sharing and managing volunteers to assist in recovery after a disaster. They are available during all phases of the disaster, from preparedness, to response, and then recovery (Kapucu et al., 2011). Also, the American Red Cross (ARC) is the leading nonprofit organization that is involved in disaster management and assists those in times of crisis. Other organizations include those within the National Response Framework (NRF), which collaborate with first responders and the government to provide disaster relief efforts. These organizations are successful because they can communicate and make important and effective decisions. Information must flow to everyone involved, especially first responders, and timely communication is crucial.

\section{Developing Collaborations Proactively}

Although collaborative workgroups are often developed reactively, proactive collaborations can often identify and overcome potential barriers, making recovery more efficient. Formal and non-formal disaster workgroups currently exist in communities. For example, each county has an Emergency Operation Centers (EOC). In addition, local and regional VOADs and community organizations active in disasters (COADs) exist, especially in areas that are vulnerable to disasters. Extension should work to identify VOADs and COADs in their communities for potential membership and partnership. In addition, working strategically to identify potential collaborations can be helpful in developing disaster communication plans. Lastly, UF/IFAS Extension and the Extension Disaster Education Network (EDEN) are positioned to serve as a hub for the development of collaborative disaster groups. As a CRO that provides research-based solutions, UF/IFAS Extension serves as an information resource to other organizations. Using this information as the foundation, collaborative workgroups can be developed to better prepare and recover from disasters.

\section{Organizations}

Community Resource Organization (CRO): A person, physical structure, community service, nonprofit, or business that provides a much-needed service or resource to a community.

National Voluntary Organizations Active in Disaster (NVOAD): An organization made up of other nonprofit organizations that come together by sharing and managing volunteers to assist in recovery after a disaster. 
Community Organizations Active in Disasters (COADs): A community organization with representatives from public, nonprofit, private, and community organizations that come together by sharing information and resources after a disaster.

Extension Disaster Education Network (EDEN): A network of Extension professionals that come together to reduce the impact of disasters through education.

American Red Cross (ARC): Leading nonprofit organization involved in disaster management that assists those in times of crisis.

National Response Framework (NRF): Set of guidelines for collaboration with first responders and the government to provide various disaster relief efforts.

Emergency Operation Centers (EOC): Control facility and central command for disaster and emergency management during a disaster or emergency.

UF/IFAS Extension: An organization of UF/IFAS faculty, scientists, educators, staff, and volunteers that provides research-based information and solutions to Florida residents.

\section{References}

Kapucu, N. (2006). Publi-Nonprofit partner-

ships for collective action in dynamic contexts of emergencies. Public Administration, 84(1), 205-220.

doi:10.1111/j.0033-3298.2006.00500.x

Kapucu, N. (2007). Nonprofit response to catastrophic disasters. Disaster Prevention and Management: An International Journal. 16(4), 551-561.

doi:10.1108/09653560710817039

Kapucu, N, Yuldhasev, F. \& Feldheim, M. A. (2011). Nonprofit organizations in disaster response and management: A network analysis. European Journal of Economic and Political Studies, 4(1), 83-112.

Miller, D. T. (2009). A life of Goodwill: Three leaders $\&$ their impact on an organization. Bloomington, IN: AuthorHouse.

Simo, G., \& Bies, A. L. (2007). The Role of Nonprofits in Disaster Response: An Expanded Model of Cross-Sector Collaboration. Public Administration Review, 67, 125-142. doi:10.1111/j.1540-6210.2007.00821.x
Word, J. K.A., \& Brower, R. (2012). "Volunteers, nonprofits, and community capacity: A case study in preparing for disaster response and recovery." Retrieved from http:// supportcenteronline.org/wp-content/uploads/2013/04/ Vol-15-Volunteers-Nonprofits-and-Community-CapacityA-Case-Study-in-Preparing-for-Disaster-Response-andRecovery.pdf 